\title{
INHIBITION OF OVULATION BY THE CORPUS LUTEUM IN THE RED KANGAROO, MEGALEIA RUFA
}

\author{
G. B. SHARMAN* AND MEREDITH J. CLARK* \\ CSIRO, Division of Wildlife Research, Canberra, Australia
}

(Received 23rd September 1966)

\begin{abstract}
Summary. When plant growth occurred following rainfall after a period of drought in western New South Wales, Australia, 35\% of a sample of sixty-five female red kangaroos were about to come into oestrus, were in oestrus or had recently been in oestrus. Only $19 \%$ of a sample taken in a comparable locality were at oestrous stages during a season of normal rainfall. After rainfall kangaroos which had failed to exhibit post-partum oestrus during the preceding drought came into oestrus and ovulated while suckling pouch young up to 163 days old. Ovulation after rainfall did not occur in kangaroos with a functional corpus luteum or a resting corpus luteum of lactation in one or other ovary. This suggests that the corpus luteum of the red kangaroo exerts an ovulation-inhibiting effect and that ovulation in this species, unlike in some other marsupials, is not inhibited by suckling. Removal of corpora lutea of lactation in suckling animals and of functional corpora lutea in non-suckling animals was followed by precocious return to oestrus. There was, however, evidence that non-suckling animals returned to oestrus following ablation of the corpus luteum sooner than did suckling animals.
\end{abstract}

\section{INTRODUCTION}

The oestrous cycle in the red kangaroo (Megaleia rufa Desm.) is 34 to 35 days long and the gestation period is about 33 days. During pregnancy ovarian and uterine changes occur that are similar in degree and duration to postoestrous phases of the oestrous cycle. Oestrus and ovulation occur soon after parturition, and intervals from the oestrus at which fertilization occurred to post-partum oestrus were not significantly different from oestrous cycle lengths (Sharman \& Calaby, 1964).

The growth of the corpus luteum formed after the post-partum ovulation in the red kangaroo is not completed during the initial period of pouchsuckling lasting about 200 days. After this time, or following the premature removal of the pouch young, the luteal cells undergo hypertrophy and hyperplasia which result in the completion of luteal growth and the development

* Present address : Department of Zoology, University of New South Wales, Kensington, New South Wales, Australia. 
of progestational changes in the uterus. A blastocyst formed from fertilization at the post-partum ovulation remains quiescent and un-implanted during the initial period of pouch-suckling and does not resume its development until the hyperplastic changes in the luteal cells have taken place (Sharman, 1963; Tyndale-Biscoe, 1963a; Clark, 1966).

Reproductive patterns similar to that of the red kangaroo, but on differing time scales, occur in six of nine species of diprotodont marsupials thus far studied (Sharman, Calaby \& Poole, 1966). A further species in this category was reported on by Tyndale-Biscoe (1965). Sharman (1955b) called the resting corpus luteum, formed at post-partum ovulation in the diprotodont Setonix brachyurus (the quokka), the corpus luteum of lactation but Tyndale-Biscoe $(1963 \mathrm{a}, \mathrm{b})$ called it the corpus luteum of post-partum ovulation.

Sharman (1955b) suggested that the corpus luteum of lactation inhibited ovulation in the lactating quokka but later (Sharman, 1963) concluded that it was the stimulus of lactation which was important in withholding ovulation. Tyndale-Biscoe (1963b) reported that eleven of 298 lactating quokkas did not have a corpus luteum of post-partum ovulation and showed no evidence of follicular growth during lactation. He concluded that follicular growth was inhibited by lactation and was independent of the presence of a resting corpus luteum. Newsome (1964a) found that some lactating red kangaroos with a pouch young lacked a corpus luteum of lactation and hence could be assumed not to have had a post-partum ovulation. After drought-breaking rains, which stimulated the growth of pasture, oestrus, ovulation and fertilization occurred in such females despite the concurrent suckling of pouch young which were up to 182 days old when ovulation finally occurred (Newsome, 1964b). These observations on the red kangaroo suggest that the corpus luteum of lactation inhibits ovulation and, if no corpus luteum of lactation is present, that ovulation occurs under favourable environmental conditions while an advanced suckling young is contained in the pouch. On the other hand oestrus does not occur in the phalangerid marsupial Trichosurus vulpecula during suckling and there is no corpus luteum of lactation present at this time (Pilton \& Sharman, 1962). In the grey kangaroo (Macropus giganteus) lactation also apparently inhibits ovulation during at least the initial period of pouch suckling (Poole \& Pilton, 1964).

In the hot climates of inland Australia where the red kangaroos were studied, short green grass and other herbage appeared a few days after rainfall. Wild red kangaroos studied during favourable seasons (Frith \& Sharman, 1964) and captive red kangaroos kept in a mild climate in grassed enclosures bred throughout the year and, except for a single specimen on one occasion, exhibited post-partum oestrus shortly after giving birth (Sharman \& Calaby, 1964). This suggested the experimental approach of surgically removing the corpus luteum of lactation to determine whether the animals would return to oestrus while suckling a pouch young. Tyndale-Biscoe (1963b) reported that removal of the developing corpus luteum of the quokka 2 days after removal of pouch young was followed by precocious return to oestrus, but if the operation was done later during the delayed cycle of reproduction oestrus recurred at the normal time, about 26 days after removal of pouch young. Corpora lutea were, 
therefore, removed from red kangaroos, at various intervals after removal of pouch young, to find if similar effects occurred in this species.

\section{Field sample}

\section{METHODS}

A sample of wild red kangaroos was taken by shooting on Salisbury Downs Station at latitude $30^{\circ} \mathrm{S}$, longitude $143^{\circ} \mathrm{E}$, New South Wales, Australia, on the nights of 24th and 25th April 1964. Mean monthly and yearly rainfalls, in the 23 years preceding the sample, for an adjacent sheep station, Barrona Downs, are given in Table 1, together with actual monthly rainfall at Salisbury Downs

TABLE 1

RAINFALL DATA* (POINTS OF RAIN RECORDED)

\begin{tabular}{|c|c|c|c|c|c|}
\hline \multirow{3}{*}{ Month } & \multicolumn{5}{|c|}{ Locality and year } \\
\hline & \multirow{2}{*}{$\begin{array}{c}\begin{array}{c}\text { Barrona } \\
\text { Downs }\end{array} \\
\begin{array}{c}\text { Average } \\
(1937 \text { to } 1960)\end{array}\end{array}$} & \multicolumn{2}{|c|}{$\begin{array}{c}\text { Salisbury } \\
\text { Downs }\end{array}$} & \multicolumn{2}{|c|}{ Mt Murchison } \\
\hline & & 1963 & 1964 & $\begin{array}{c}\text { Average } \\
(1931 \text { to } 1960)\end{array}$ & 1963 \\
\hline $\begin{array}{l}\text { January } \\
\text { February } \\
\text { March } \\
\text { April } \\
\text { May } \\
\text { June } \\
\text { July } \\
\text { August } \\
\text { September } \\
\text { October } \\
\text { November } \\
\text { December }\end{array}$ & $\begin{array}{r}122 \\
143 \\
86 \\
47 \\
67 \\
48 \\
69 \\
54 \\
42 \\
100 \\
62 \\
62\end{array}$ & $\begin{array}{r}188 \\
64 \\
277 \\
0 \\
70 \\
99 \\
11 \\
0 \\
58 \\
0 \\
0 \\
0\end{array}$ & $\begin{array}{r}42 \\
81 \\
0 \\
239\end{array}$ & $\begin{array}{r}79 \\
97 \\
101 \\
74 \\
80 \\
69 \\
63 \\
56 \\
46 \\
92 \\
83 \\
65\end{array}$ & $\begin{array}{r}199 \\
5 \\
280 \\
106 \\
94 \\
127 \\
85 \\
121 \\
10 \\
29\end{array}$ \\
\hline Total & 902 & 767 & & 905 & \\
\hline
\end{tabular}

* Data from Commonwealth of Australia, Department of the Interior, Bureau of Meteorology, except Salisbury Downs data obtained from station records.

for 1963 and the months of 1964 preceding the sample. The Salisbury Downs sample was compared with a sample taken 115 miles SSE at Mt Murchison Station in November and December 1963. Mt Murchison rainfall is also given in Table 1. Both localities lie between the 8 and 10 in. rainfall isohyets and receive a comparable amount of rain.

During the 6 months preceding the taking of the Salisbury Downs sample drought conditions prevailed and only 123 points of rain fell compared to the average 575 points. The drought broke on 14th and 15th April and further heavy rain fell on 20th, 21st and 22nd April giving a total fall of 239 points before the sample was taken (April average rainfall $=47$ points). The sample was taken as soon after the rain as it was possible to work in the area. The Mt Murchison sample was taken during a season when the rainfall was about average for the area, 466 points of rain, compared to the average 406 points, having fallen during the 6 months preceding the sample. 
The animals were shot from a four-wheel drive vehicle equipped with a spotlight. Each female was weighed and measured and the molar eruption stage was scored for later use in determining the age (Sharman, Frith \& Calaby, 1964). The pouch was examined to see if one or more teats were enlarged and lactating, and if a young was present its weight and standard body measurements were taken and later used for age determination (Sharman et al., 1964). The reproductive systems were removed, examined and fixed immediately in alcohol-formalin-acetic acid. Material for histological study was embedded in paraffin wax, sectioned at 6 to $8 \mu$ and stained with Ehrlich's haematoxylin and eosin.

\section{Experimental techniques}

The animals were kept in grassed enclosures at Canberra and their diet was supplemented with oats and pasture hay. Before surgery they were anaesthetized with Veterinary Nembutal Sodium as described by Sharman \& Calaby (1964). When necessary, further anaesthetic was administered through an ear vein during the operation. The ovaries and uteri were exposed through a median ventral incision in the anterior pouch region and the corpus luteum was located by examination of both ovaries. The corpus luteum was removed with the whole or part of the ovary containing it and this was fixed, sectioned and stained in the same way as the field material. Part of an ovary which did not contain the corpus luteum was removed from sham-operated animals. During the operations, young in the pouch were left there, attached to a teat, and those not later removed in the course of the experiment were retained to the end of pouch life.

All animals used had mated in post-partum oestrus and hence could be expected to be carrying a dormant blastocyst. Operated females were returned to enclosures in which a male was present and were thereafter examined daily to check for the occurrence of mating. Vaginal smears were taken every 2nd day and these were fixed, stained and examined according to the methods given by Sharman \& Calaby (1964). Pouch young were removed from animals which had not returned to oestrus 60 days after operation.

\section{RESULTS}

\section{Effect of environment on reproduction in the wild population}

In captivity female red kangaroos reached sexual maturity when 17 to 20 months old (Sharman \& Calaby, 1964) at molar eruption stage about MI.2 (Sharman et al., 1964). In this study all female red kangaroos at MI.2 and later stages of molar eruption were regarded as potentially capable of breeding and were included in the calculations.

In Table 2, the females taken in the field sample are grouped according to the reproductive stage using the criteria of Sharman (1964). To exclude the possibility of confusing post-partum oestrus with oestrus during later stages of pouch suckling (Newsome, 1964b), or with the oestrus that occurs after vacation of the pouch by the 235-day-old young (Sharman \& Calaby, 1964), females with pouch young 15 to 200 days old were placed in a separate class.

In the Salisbury Downs sample seven females out of a total of thirty-seven 
with young aged 15 to 200 days had recently been in oestrus or were about to come into oestrus 10 to 11 days after the first April rainfall. They did not have a corpus luteum of lactation before the rainfall and hence had failed to undergo post-partum oestrus. However, they came into oestrus and ovulated after drought-breaking rains fell despite the presence of suckling young, aged between 27 and 163 days, in their pouches. Similar effects in red kangaroos were observed by Newsome (1964a, b). The proportions of oestrous and non-oestrous females with pouch young 15 to 200 days old were highly significantly different in the Salisbury Downs and Mt Murchison samples $(P<0.001)$. In captive red kangaroos oestrus occurred at a mean interval of 2.3 days post partum

TABLE 2

REPRODUGTIVE STAGE OF FEMALE RED KANGAROOS AT MI.2 AND LATER STAGES OF MOLAR ERUPTION TAKEN IN THE SAMPLES

\begin{tabular}{|c|c|c|c|c|}
\hline \multirow{2}{*}{ Stage of reproductive cycle } & \multicolumn{2}{|c|}{ Salisbury Downs } & \multicolumn{2}{|c|}{ Mt Murchison } \\
\hline & No. & $\%$ & No. & $\%$ \\
\hline $\begin{array}{l}\text { (a) Pouch young } 15 \text { to } 200 \text { days old } \\
\text { Pro-oestrous, oestrous and post- } \\
\text { oestrous phases } \\
\text { Quiescent phase }\end{array}$ & $\begin{array}{r}7 \\
30\end{array}$ & $\begin{array}{l}10 \cdot 8 \\
46 \cdot 2\end{array}$ & $\begin{array}{r}0 \\
123\end{array}$ & $\begin{array}{r}0.0 \\
55.9\end{array}$ \\
\hline $\begin{array}{l}\text { (b) Pouch young }<15 \text { days or }>200 \text { days old } \\
\text { Pro-oestrous, oestrous, and post- } \\
\text { oestrous phases } \\
\text { Luteal phase } \\
\text { Quiescent phase }\end{array}$ & $\begin{array}{l}1 \\
1 \\
3\end{array}$ & $\begin{array}{l}1 \cdot 5 \\
1.5 \\
4 \cdot 8\end{array}$ & $\begin{array}{r}8 \\
16 \\
26\end{array}$ & $\begin{array}{r}3.6 \\
7.3 \\
11.8\end{array}$ \\
\hline $\begin{array}{l}\text { (c) No young in pouch } \\
\text { Pro-oestrous, oestrous and post- } \\
\text { oestrous phases } \\
\text { Luteal phase } \\
\text { Non-breeding }\end{array}$ & $\begin{array}{r}15 \\
1 \\
7\end{array}$ & $\begin{array}{r}23.0 \\
1.5 \\
10.8\end{array}$ & $\begin{array}{l}11 \\
10 \\
26\end{array}$ & $\begin{array}{r}5.0 \\
4.5 \\
11.8\end{array}$ \\
\hline Total & 65 & & 220 & \\
\hline
\end{tabular}

(Sharman, 1963) and red kangaroos taken at Mt Murchison during a 3-year period of above average rainfall apparently had a similar pattern of reproduction (Frith \& Sharman, 1964). There was also a significantly higher number of females with no pouch young but which showed oestrous stages (Table 2c) in the Salisbury Downs sample than in the Mt Murchison sample $(P<0.001)$.

None of the females suckling pouch young 15 to 200 days old, and which had a corpus luteum of lactation, came into oestrus after the rain had fallen. It would appear, therefore, that the corpus luteum of lactation has an ovulationinhibiting function and that, in its absence, ovulation occurs in response to intake of fresh green grass and herbage which grew rapidly after rainfall in the regions where the animals were studied.

The Salisbury Downs and Mt Murchison samples were taken at different times of the year and the higher percentage of females in oestrus in the Salisbury Downs sample might suggest that they were taken during a preferred time of 
annual breeding. Three years study of the Mt Murchison population failed to demonstrate any annual breeding cycle (Frith \& Sharman, 1964) and Newsome (1965) concluded that breeding in the red kangaroo could best be described as opportunistic.

\section{Effect of corpus luteum removal on animals suckling a pouch young}

Corpora lutea of lactation were removed from six animals which were suckling pouch young 4 to 60 days old (mean age, 36 days). Five of these returned to oestrus 14,17,20, 21 and 60 days after operation. As the sixth female had not come into oestrus at 60 days the pouch young was removed. Oestrus occurred 3 days later; so it is likely that pro-oestrous changes were initiated before the young was removed and that oestrus would have recurred at 63 days had the young been retained. The mean interval from removal of corpus luteum of lactation to return to oestrus in experimental females suckling a pouch young was thus 32.5 days. One of the two control animals was killed 60 days after operation and there was no evidence of return to oestrus. The other returned to oestrus 34 days after removal of the pouch young at 60 days after operation, i.e. when expected. Non-operated animals with pouch young which were allowed to rear their young until they left the pouch, did not come into oestrus until the young were over 235 days old (Sharman \& Calaby, 1964). In operated animals the ages of pouch young, when the females returned to oestrus, ranged from 21 to 119 days, so corpus luteum removal clearly resulted in precocious return to oestrus.

None of the dormant blastocysts expected to have been present in the operated females suckling a pouch young completed development.

\section{Effect of corpus luteum removal on animals not suckling a pouch young}

Corpora lutea of lactation or derived developing corpora lutea were removed from six animals 0 to 11 days after their pouch young were removed (mean time of operation after removal of pouch young was 6 days). Five of these returned to oestrus $8,9,10,13$ and 18 days after operation (mean, 11.6 days), but the sixth female did not return to oestrus until 60 days after operation (mean of all operated animals, 20 days). Two operated control animals from which nonluteal portions of one ovary were removed at 11 days after removal of pouch young returned to oestrus 25 days later, i.e. 36 days after removal of pouch young. Ten non-operated females, deprived of their pouch young, returned to oestrus at an average of 34.5 days later (s.D. 1.9 days) (Sharman, 1965a). Thus surgical removal of the functional corpus luteum up to 11 days after removal of pouch young resulted in precocious return to oestrus. Leaving aside the three animals from both groups which took 60 days or more to return to oestrus after corpus luteum removal, and which may have been adversely affected by the operation, the results indicate a more rapid return to oestrus by females not suckling a pouch young.

None of the females from which corpora lutea were removed subsequently produced a young which could have been derived from the dormant blastocyst which it was expected they were carrying when their pouch young were removed. 


\section{DISCUSSION}

Newsome (1964b) found that in three samples of red kangaroos taken in the Alice Springs area in the Northern Territory of Australia after droughtbreaking rain, eighteen animals suckling young aged between 9 and 182 days were about to undergo, were undergoing or had just undergone oestrus. Similarly, in the sample taken at Salisbury Downs seven animals with pouch young aged between 27 and 163 days, were at oestrous stages (pro-oestrus and post-oestrus). None of the animals from either area which were at oestrous stages while suckling a pouch young, had a corpus luteum of lactation in either ovary. Fifteen of twenty-two Salisbury Downs animals without pouch young were at oestrous stages and the condition of their pouches and ovaries indicated that at least nine of these had been in a non-breeding condition (immature or anoestrous) for some time before pasture growth started. These results indicate that when environmental conditions became favourable, after a period of severe drought, females that were potentially capable of breeding came into oestrus except those that had a corpus luteum-quiescent, mature or beginning to regress. Lactation and the presence of a young in the pouch did not inhibit follicle maturation and ovulation. Similar results were obtained by Newsome (1964b).

The quokka (Setonix brachyurus) resembles the red kangaroo in having a postpartum oestrus but, unlike the red kangaroo, it has a seasonal (summer) anoestrus (Sharman, 1955a). Tyndale-Biscoe (1963a) concluded that ovulation in the quokka was inhibited independently of the presence of the corpus luteum but he did not state at what time of the year the observations were made. Three of the animals had an enlarged follicle 18 to 23 days after removal of their pouch young.

Tyndale-Biscoe (1963b) recorded premature ovulation in the quokka only when the corpus luteum was removed within 2 days of removal of pouch young, but in the red kangaroo premature ovulation occurred following corpus luteum ablation as late as 11 days after removal of pouch young. A grey kangaroo returned to oestrus 13 days after removal of a corpus luteum 8 days postoestrus (Poole \& Pilton, 1964). Removal of functional corpora lutea from the ovaries of the cow, the ewe and the guinea-pig hastens the onset of oestrus (Everett, 1961).

Sharman (1963) suggested that the stimulus of lactation was important in withholding ovulation in marsupials and that post-partum oestrus occurred in macropodids because the onset of lactation was sufficiently delayed by the comparatively long pregnancy to allow pre-ovulatory changes to be initiated in the ovary. The occurrence of oestrus while young aged up to 182 days occupied the pouch suggests that this explanation is invalid. Sharman (1955b) earlier suggested that the small corpus luteum of lactation of the quokka had an ovulation-inhibiting effect and that it performed a second function-the induction of a uterine luteal phase-when it reached a larger size after removal of the young from the pouch. This appears to be a satisfactory explanation for the red kangaroo. In the phalangerid marsupial, Trichosurus vulpecula (the brush possum), the gestation period (17.5 days) is much shorter than the length of the 
oestrous cycle (26 days) and post-partum ovulation is not a normal feature of reproduction. As in other marsupials, ovarian and uterine phases, like those of the oestrous cycle, occur during pregnancy but the young is born during the postluteal phase rather than during the pro-oestrous phase as happens in marsupials exhibiting post-partum ovulation. This suggests that the suckling stimulus exerted by the brush possum young prevents return to oestrus, particularly as female brush possums, prematurely deprived of suckling young during the breeding season, returned to oestrus about 8 days later (Pilton \& Sharman, 1962) and non-mated females, to which newborn young were transferred at the appropriate post-oestrous stage, failed to return to oestrus while the foster young occupied their pouches (Sharman, 1962). The suckling stimulus presumably also inhibits ovulation in Didelphis in the absence of a corpus luteum of lactation (Hartman, 1923). The macropodid Macropus giganteus (the grey kangaroo) does not have a post-partum ovulation and ovulation does not usually occur while young occupy the pouch. Females returned to oestrus 7 to 13 days after removal of pouch young in the breeding season (Poole \& Pilton, 1964). A small proportion of females carrying pouch young over 180 days old come into oestrus, mate and ovulate, and enter a quiescent phase similar to that which follows

TABLE 3

TIMES OF RETURN TO OESTRUS IN ANIMALS WITHOUT CORPORA LUTEA AFTER RAINFALL AND IN THOSE DEPRIVED OF CORPORA LUTEA BY OPERATION

\begin{tabular}{l|r|r|r|r}
\hline \multicolumn{1}{c|}{ Description of animals } & $n$ & \multicolumn{3}{|c}{ Days until onset of oestrus } \\
\cline { 2 - 5 } & & \multicolumn{1}{|c|}{ Range } & Mean & Variance \\
\hline Wild, with pouch young & 7 & about 10 to 12 & about 10 & \\
Domestic, with pouch young & 4 & 14 to 21 & 18.0 & 7.5 \\
Domestic, without pouch young & 5 & 8 to 18 & 11.6 & 13.0 \\
\hline
\end{tabular}

post-partum ovulation in the red kangaroo (Kirkpatrick, 1965; Clark \& Poole, 1967). It appears that, in this species, the stimulus of pouch suckling is usually sufficient to inhibit ovulation but that corpus luteum inhibition of ovulation may occur in some females with advanced pouch young.

The experiments reported above suggest some influence of suckling on speed of return to oestrus following ablation of the corpus luteum in the red kangaroo. If it be assumed that those females which took 60 or more days to return to oestrus were adversely affected by the operation then this leaves four females with pouch young which returned to oestrus at a mean interval of 18 days after operation and five females without pouch young which returned to oestrus at a mean interval of 11.6 days after operation. Animals without pouch young, thus, returned to oestrus in a significantly shorter interval than did animals with pouch young $(P<0.05)$ (Table 3$)$. On the other hand, wild females with pouch young, but without a corpus luteum of lactation, returned to oestrus about 10 days after drought-breaking rains fell. This is an extremely rapid response considering that a few days elapsed, after rainfall, before green growth appeared. 
Newsome (1964b) believed that during severe drought the failure of ovarian follicles to enlarge was due to failure of follicle-stimulating hormone secretion. The rapid response after rain (oestrus occurred in some animals studied here less than 10 days after rain fell) suggests that failure of some animals to ovulate during drought is not due to low nutritional state, as Newsome suggested, but to the lack of some specific substance that is available after rain and in good seasons, but not during drought. It may, perhaps, be present in green, but not in dry, grass. The problem also arises that, if a pituitary factor is necessary to maintain lactation in the red kangaroo, then this is adequately secreted while follicle-stimulating hormone secretion is inadequate. Sharman (1965b) showed that development of the corpus luteum of lactation in the red kangaroo was inhibited by frequent suckling of young and by injection of oxytocin. The relationships between environmental factors, pituitary, mammary glands, corpus luteum and ovarian follicle, are obviously complex and demand further investigation. This investigation does, however, appear to have demonstrated that ovulation in the red kangaroo on an adequate level of nutrition may only be inhibited when a resting or functional corpus luteum is present. Suckling may affect the time of onset of ovulation but does not, by itself, inhibit ovulation.

\section{ACKNOWLEDGMENTS}

We wish to thank Mr Tom Davis for allowing us to collect and study kangaroos on his property, Salisbury Downs, and our colleague, Mr P. Bailey, for his help in the taking of the field sample. We are grateful to Mr P. Martensz, Mr J. Merchant and Mr L. Roux for assistance in the field, in the operating theatre and in the care of the captive animals.

\section{REFERENCES}

Clark, M. J. (1966) The blastocyst of the red kangaroo, Megaleia rufa (Desm.) during diapause. Aust. F. Zool. 14, 19.

Clark, M.J. \& Poole, W. E. (1967) The reproductive system and embryonic diapause in the female grey kangaroo, Macropus giganteus. Aust. F. Zool. 14, 441.

EvereTr, J. W. (1961) The mammalian female reproductive cycle and its controlling mechanisms. In: Sex and Internal Secretions, Vol. 1, p. 506. Ed. W. C. Young. Williams \& Wilkins, Baltimore.

Frith, H. J. \& Sharman, G. B. (1964) Breeding in wild populations of the red kangaroo, Megaleia rufa. CSIRO Wildl. Res. 9, 86.

Hartman, C. G. (1923) The oestrous cycle of the opossum, Didelphis virginiana. Am. F. Anat. 32, 353.

KirkPATrick, T. H. (1965) Studies of Macropodidae in Queensland. 3. Reproduction in the grey kangaroo in southern Queensland. Qd 7. agric. Anim. Sci. 22, 319.

Newsome, A. E. (1964a) Anoestrus in the red kangaroo, Megaleia rufa (Desmarest). Aust. F. Zool. 12, 9.

Newsome, A. E. (1964b) Oestrus in the lactating red kangaroo, Megaleia rufa (Desmarest). Aust. F. Zool. $12,315$.

Newsome, A. E. (1965) Reproduction in natural populations of the red kangaroo, Megaleia rufa (Desmarest), in Central Australia. Aust. 7. Zool. 13, 735.

Pilton, P. E. \& Sharman, G. B. (1962) Reproduction in the marsupial Trichosurus vulpecula. F. Endocr. $25,119$.

Poole, W. E. \& Pilton, P. E. (1964) Reproduction in the grey kangaroo, Macropus canguru, in captivity. CSIRO Wildl. Res. 9, 218.

Sharman, G. B. (1955a) Studies on marsupial reproduction. 2. The oestrous cycle of Setonix brachyurus. Aust. 7. Zool. 3, 44. 
Sharman, G. B. (1955b) Studies on marsupial reproduction. 3. Normal and delayed pregnancy in Setonix brachyurus. Aust. F. Zool. 3, 56.

Sharman, G. B. (1962) The initiation and maintenance of lactation in the marsupial Trichosurus vulpecula. 7. Endocr. 25, 375.

Sharman, G. B. (1963) Delayed implantation in marsupials. In: Delayed Implantation, p. 3. Ed. A. C. Enders. Chicago University Press.

Sharman, G. B. (1964) The female reproductive system of the red kangaroo, Megaleia rufa. CSIRO Wildl. Res. 9, 50.

Sharman, G. B. (1965a) The effects of suckling on normal and delayed cycles of reproduction in the red kangaroo. Z. Säugetierk. 30, 10.

Sharman, G. B. (1965b) The effects of the suckling stimulus and oxytocin injection on the corpus luteum of delayed implantation in the red kangaroo. Proc. 2nd int. Congr. Endocrinology. Excerpta Medica International Congress Series No. 83, 669.

Sharman, G. B. \& Calaby, J. H. (1964) Reproductive behaviour in the red kangaroo, Megaleia rufa, in captivity. CSIRO Wildl. Res. 9, 58.

Sharman, G. B., Calaby, J. H. \& Poole, W. E. (1966) Patterns of reproduction in female diprotodont marsupials. In: Comparative Biology of Reproduction in Mammals. Symposia of the Zoological Society of London No. 15. Ed. I. W. Rowlands. Academic Press, London.

Sharman, G. B., Frith, H. J. \& Calaby, J. H. (1964) Growth of the pouch young, tooth eruption and age determination in the red kangaroo, Megaleia rufa. CSIRO Wildl. Res. 9, 20.

TyNDALE-Biscoe, C. H. (1963a) The role of the corpus luteum in the delayed implantation of marsupials. In: Delayed Implantation, p. 15. Ed. A. C. Enders. Chicago University Press.

Tyndale-Biscoe, G. H. (1963b) Effects of ovariectomy in the marsupial Setonix brachyurus. F. Reprod. Fert. 6, 25.

Tyndale-Biscoe, C. H. (1965) The female urogenital system and reproduction of the marsupial Lagostrophus fasciatus. Aust. F. Zool. 13, 255. 